\title{
Online Dating dalam Relasi Percintaan Friends with Benefit di Media Sosial Whisper
}

\author{
Aissyah Dwi Fitriyani $^{1^{*}}$, Cici Eka Iswahyuningtyas ${ }^{2}$ \\ ${ }^{1,2}$ Program Studi Ilmu Komunikasi Fakultas Ilmu Komunikasi, Universitas Pancasila \\ Jl. Raya Lenteng Agung No. 56-80, Srengseng Sawah, Jakarta Selatan, 12640, Indonesia \\ Email: aissyahdwi24@gmail.com ${ }^{1 *}$; ciciekaiswahyuningtyas@yahoo.com² \\ *Corresponding author
}

\begin{abstract}
Dating in Friends with Benefit (FWB) relationship is different from online dating in general because in this relationship there is no agreement or commitment. The research objective is to analyze the stages of relationship development carried out through social media, namely closeness or intimacy, self-disclosure, penetration, and depenetration. The theory used in seeing the development of FWB relationships on Whisper's social media is the theory of social penetration. This study used a qualitative method by conducting in-depth interviews with adolescents aged 17-22 years. The results showed that in developing relationships, FWB aims to seek entertainment, expand relationships, and make friends. Teens who are involved in FWB have an understanding of online dating through Whisper's social media as a positive and efficient thing. This research contributes in the form of recommendations to online dating managers and users to pay attention to virtual communication ethics, make preparations such as looking for information about relationships that are run virtually to know the good and bad and not to harm either party. Keywords: Friends with Benefits; Online Dating; Social Penetration; Whisper
\end{abstract}

\begin{abstract}
Abstrak
Kencan dalam hubungan Friends with Benefit (FWB) berbeda dengan kencan online pada umumnya karena pada hubungan ini tidak ada kesepakatan ataupun komitmen. Tujuan penelitian yaitu menganalisis tahapan pengembangan hubungan yang dijalankan melalui media sosial yaitu kedekatan atau keakraban, keterbukaan diri, penetrasi dan depenetrasi. Teori yang digunakan dalam melihat pengembangan hubungan FWB di media sosial Whisperyaitu teori Penetrasi Sosial. Penelitian ini menggunakan metode kualitatifdengan melakukan wawancara mendalam kepada remaja usia 17-22 tahun. Hasil penelitian menunjukkan dalam pengembangan hubungan FWB bertujuan untuk mencari hiburan, memperluas relasi serta mencari teman. Remaja yang terlibat FWB memiliki pemahaman mengenai kencan online melalui media sosial Whisper sebagai suatu hal yang positif dan efisien. Penelitian ini memberikan kontribusi berupa rekomendasi kepada pengelola dan pengguna online dating untuk memerhatikan etika komunikasi virtual, melakukan persiapan seperti mencari informasi mengenai hubungan yang dijalankan secara virtual agar mengetahui baik dan buruknya serta tidak merugikan salah satu pihak.
\end{abstract}

Kata kunci: Friends with Benefit; Kencan Online; Penetrasi Sosial; Whisper

\section{Pendahuluan}

Saat ini kencan online mulai dipilih oleh masyarakat sebagai alternatif untuk mencari pasangan, baik untuk hubungan yang serius menuju pernikahan atau sekadar mencari kesenangan. Seiring dengan berkembangnya teknologi, mencari jodoh pun dapat dilakukan melalui ponsel atau komputer. Jika pada jaman dahulu ketika sebuah biro jodoh atau biro pencarian pasangan mewajibkan kedua calon pasangan untuk saling bertemu dan bertatap muka terlebih dahulu, saat ini hal tersebut dapat dilakukan hanya dengan mengunduh sebuah aplikasi pencari jodoh atau online dating.
Situs kencan internet terbesar yang berada di Amerika Serikat, match.com melaporkan memiliki tujuh juta pengguna di AS dan tambahan dua juta di seluruh dunia pada 2006 (Arvidsson, 2006). Pada akhir Februari 2011, jumlah anggota terdaftar hampir dua kali lipat. Di Indonesia, data yang dihimpun dari setipe. com menunjukkan bahwa pada tahun 2015 pengguna situs kencan online meningkat tajam.

Terdapat beberapa situs dan aplikasi kencan online yang cukup dikenal di wilayah Indonesia, seperti setipe.com, okcupid. com, indonesiancupid.com, maupun aplikasi kencan seperti Tinder dan BeeTalk. Situs dan 
aplikasi tersebut cukup banyak digunakan oleh masyarakat Indonesia. Hal tersebut dibuktikan dengan hasil survei yang dilakukan oleh Sensor Tower, menyebutkan bahwa pengguna layanan aplikasi online dating di Indonesia adalah sebesar $0,11 \%$ dari total populasi penduduk Indonesia (Sari dan Kusuma, 2018). Hal tersebut dikarenakan aplikasi tersebut cukup mudah diakses dan digunakan oleh banyak orang di Indonesia. Hal itu juga dijelaskan dalam penelitian Abadi, Sukmawan, dan Utari (2015) yang berjudul media sosial dan pengembangan hubungan interpersonal remaja di Sidoarjo.

Penelitian tersebut menjelaskan bahwa, pengungkapan identitas di dunia maya menjadi hal yang sangat penting dalam pengembangan hubungan di dunia maya. Hal ini terkait dengan tingkat kepercayaan dan kedekatan yang hendak dibangun oleh masing-masing individu. Proses komunikasi interpersonal atau komunikasi yang terjadi secara dua arah merupakan proses pengiriman dan penerimaan pesan di antara dua orang atau lebih dan di antara sekelompok kecil orang, dengan berbagai pengungkapan makna (meaning) dalam kegiatan komunikasi melalui jejaring media sosial (Bahfiarti, 2012). Hubungan interpersonal yang dibangun dengan individu, baru bisa berkembang sebagaimana hubungan interpersonal di dunia nyata, meskipun masing-masing individu belum pernah berjumpa secara tatap muka sekalipun.

Pengguna situs jejaring dapat membangun pertemanan, persahabatan bahkan percintaan dengan bahasa verbal yang dikirimkan melalui situs jejaring. Kedekatan yang dibangun dengan bahasa verbal, individu seolah-olah dapat merasakan interaksi secara langsung dengan teman komunikasinya, bahkan saat ini sudah jamak dijumpai beberapa hubungan perkenalan di dunia maya berkembang pada hubungan percintaan yang dirasionalisasikan dalam dunia nyata sampai dengan hubungan pernikahan meskipun masing-masing individu belum pernah mengenal sebelumnya (Indriyati, 2015; Žakelj, Kocon, Švab, dan Kuhar, 2015).
Hal utama yang paling diperhatikan oleh para pengguna kencan online adalah presentasi diri. Fenomena kencan online di media sosial merupakan sekumpulan pengguna internet yang membentuk jaringan hubungan personal di media sosial, sehingga memunculkan sebuah fenomena baru yaitu, Friends with Benefit atau biasa disingkat FWB. Friends with Benefit merupakan isu yang sudah lama menjadi perdebatan ketika seseorang menjalin hubungan relasi percintaan.

Jika di dalam penelitian sebelumnya biasanya seseorang menjalin hubungan kencan yang dilandasi hubungan cinta melalui media sosial secara online, berbeda dengan fenomena FWB dimana hubungan tersebut tidak dijalankan dengan perasaan saling menyukai maupun cinta. FWB adalah fenomena pergaulan bebas remaja yang bersifat intim dengan tanpa emosional dan komitmen, dimana hubungan ini tidak memiliki sebuah keterikatan tetapi mengutamakan sebuah keuntungan (Putri, 2015). Seiring berjalannya waktu dan perkembangan teknologi yang semakin pesat, FWB membentuk sebuah komunitas yang dijalankan secara online melalui media sosial dan membentuk sebuah komunitas virtual. Adapun konsep virtual tersebut dikarenakan adanya 'bandwidth'sebagaimana penanda utama untuk terkoneksi dengan dunia virtual. Tanpa disadari, komunitas manusia telah hidup dalam dua dunia kehidupan, yaitu kehidupan nyata dan kehidupan masyarakat maya (cyber community).

Kemunculan aplikasi atau situs kencan online menggeser perilaku berelasi romantis seseorang (Ben-Ze'ev, 2014). Hal ini berhubungan dengan suatu konsep dalam komunikasi yaitu pengembangan hubungan sosial atau penetrasi sosial antar individu, yang berkembang seiring lahirnya media baru dan pesatnya penggunaan media komunikasi berbasis internet. Dinamika kehidupan manusia diwarnai dengan berbagai macam situasi dan kondisi, contohnya saat manusia merasa kesepian atau tidak memiliki teman untuk berbagi cerita maka hal ini berhubungan dengan fenomena sosial yaitu friends with benefit atau yang lebih dikenal dengan singkatannya yaitu FWB. 
FWB didukung dengan adanya media sosial anonim seperti Whisper dimana seseorang mencari teman dan dapat melakukan komunikasi antara dirinya dan orang lain untuk selanjutnya melakukan FWB. Whisper merupakan sebuah media sosial anonim dimana setiap penggunanya dapat mengungkapkan dan menuliskan hal-hal apapun yang ada di pikirannya ataupun mengenai aktivitas kesehariannya. Media sosial ini memang cukup menunjukkan sisi anonimitas meski disediakan sebuah profil sederhana bagi para penggunanya.

Hal tersebutlah yang membuat Whisper menjadi wadah bagi sebagian komunitas virtual FWB untuk mengungkapkan dan menuliskan mengenai yang sedang dirasakan. Dimensi pertama adalah keluasan topik (topic breadth), yang kedua adalah frekuensi keluasan (breadth frequency), dan yang ketiga adalah dimensi waktu (topic time). Kehadiran media sosial di kalangan remaja, membuat ruang privat seseorang melebur dengan ruang publik (Ayun, 2015).

Adanya keterbukaan dalam berkomunikasi melalui proses tersebut, maka manusia yang sedang menjalin suatu hubungan dapat mengenal pribadi secara baik antara satu dengan yang lain. Saling mengetahui perasaan serta informasi diri satu dengan yang lain, memberi dukungan, serta mengetahui harapan-harapan orang lain, dapat menghindari hambatan-hambatan yang mungkin dapat terjadi dalam suatu hubungan.

Media sosial anonim Whisper dengan segala kapasitasnya sebagai sebuah platform komunikasi menjadi sarana bagi para pengguna FWB untuk dapat berinteraksi, baik untuk mencari teman atau pun pasangan. Fenomena yang sering terdengar belakangan ini, bahwa beberapa orang yang melakukan kencan online merasa tertipu oleh pasangannya setelah mereka bertemu secara offline (face to face). Hal ini seperti yang diungkapkan Hikmah dan Rahardjo (2018) dalam penelitiannya yang menemukan bahwa para pengguna situs kencan online membentuk kepribadiannya dalam tingkat "sangat baik" atau "di atas ratarata". Memang, pembohongan identitas ini bisa juga terjadi pada komunikasi tatap muka atau komunikasi secara offline, namun kemungkinan keberhasilannya lebih sedikit daripada pembohongan yang dilakukan secara online.

Hal ini dikarenakan komunikasi secara online memiliki sifat yang asinkron, minim tanda-tanda nonverbal, penggunanya bersifat anonim, serta kontennya dapat diedit sesuai dengan keinginan pengguna (Griffin, 2006).

Penelitian tentang aplikasi kencan online sudah dilakukan oleh Lawado dan Puspita (2020). Penelitian tersebut membahas proses komunikasi antarpersonal pada pasangan pengguna aplikasi kencan online Tinder di kalangan mahasiswa Universitas Negeri Surabaya. Hasil penelitian menunjukkan komunikasi antarpersonal yang terjadi pada pasangan yang berbasis pada aplikasi kencan online dapat terjadi dari proses pendekatan yang dilakukan dalam interaksinya melalui tahapan dari penetrasi sosial yang telah dilakukan. Beberapa penelitian lain tentang aplikasi kencan online juga telah dilakukan Sari dan Rina (2018), Andhika \& Julianti (2021), Andriani, Diana dan Sitti (2019), Mellania dan Tjahjawulan (2020), dan Cessia dan Lestari (2017).

\section{Teori Penetrasi Sosial}

FWB yang dijalankan oleh remaja dengan konsep virtual didukung dengan adanya media sosial anonim seperti Whisper, dimana seseorang mencari teman dan dapat melakukan komunikasi antara dirinya dan orang lain untuk selanjutnya melakukan hubungan FWB. Whisper merupakan sebuah media sosial anonim dimana setiap penggunanya dapat mengungkapkan dan menuliskan hal-hal apapun yang ada di pikirannya ataupun mengenai aktivitas kesehariannya. Hal ini berhubungan dengan suatu konsep dalam komunikasi yaitu pengembangan hubungan sosial atau penetrasi sosial antar individu, yang berkembang seiring lahirnya media baru dan pesatnya penggunaan media komunikasi berbasiskan internet.

Cara untuk mendapatkan ruang pembicaraan antara masing-masing pihak dibutuhkan komunikasi yang seb elumnya tidak dekat, namun menjadi dekat bahkan intim. Hubungan komunikasi yang terjadi diantara dua orang, 
dimulai pada tahapan yang paling ringan dan bergerak pada sebuah proses menuju tahapan yang lebih intim atau lebih dekat. Tidak semua hubungan terletak pada titik yang ekstrem, tidak intim maupun intim. Penetrasi sosial adalah suatu proses hubungan dimana terjadi pergerakan kedekatan hubungan yang dangkal menjadi hubungan yang lebih intim. Keintiman seseorang tidak hanya dinilai dari kedekatan fisik, tetapi dapat juga termasuk dalam kedekatan intelektual dan emosi saat berbagi informasi kegiatan yang dilakukan. Konsep yang ada pada penetrasi sosial melihat tahap-tahap ketika seseorang menjalin komunikasi melalui media online mulai dari tahapan kedekatan atau keakraban, keterbukaan diri, penetrasi dan depenetrasi. Teori penetrasi sosial berperan penting dalam memusatkan perhatian kita pada perkembangan hubungan.

Proses perkembangan hubungan dalam meningkatkan keakraban dalam suatu perkenalan dikenal dengan penetrasi sosial (Altman dan Taylor, 1973). Teori ini menggambarkan pola pengembangan hubungan yang diidentifikasi sebagai penetrasi sosial. Penetrasi sosial adalah suatu proses hubungan di mana terjadi pergerakan kedekatan hubungan yang dangkal menjadi hubungan yang lebih intim. Lapisan sisi kulit terluar dari kepribadian manusia adalah apa yang terbuka dan diperlihatkan publik, hal-hal yang sering kita dapat perlihatkan kepada orang lain secara umum, tidak aka nada yang ditutup-tutupi.

Menurut teori penetrasi sosial keputusan tentang seberapa dekat dalam suatu hubungan ditentukan oleh prinsip untung-rugi (reward costs analysis). Sesudah melakukan tahap perkenalan dengan seseorang pada dasarnya kita akan menghitung faktor untung rugi yang terjadi di dalam hubungan kita dengan orang lain, atau disebut dengan indeks kepuasan dalam hubungan (index of relational satisfaction). Hal tersebut berkaitan dengan konsep pertukaran sosial.

Dalam masa-masa awal hubungan dengan seseorang biasanya kita melihat penampilan fisik atau tampilan luar dari orang tersebut, kesamaan latar belakang, dan banyaknya kesamaan atau kesamaan terhadap hal-hal yang disukai atau disenangi. Hal inilah yang mendorong seseorang menjalankan suatu hubungan, namun berbeda ketikamenjalankanhubunganFriendswithBenefit melalui media sosial anonim, tanpa seseorang membuat profil diri dengan foto berwajah tampan maupun melihat penampilan fisik.

Berdasarkan paparan tersebut, penelitian ini bertujuan untuk menganalisis pengembangan hubungan dalam online dating yang terjadi pada relasi percintaan friends with benefit di media sosial whisper.

\section{Metode Penelitian}

Sesuai dengan sifat dan karakter permasalahan data yang diangkat dalam penelitian ini pendekatan penelitian yang digunakan yaitu kualitatif. Pendekatan kualitatif digunakan untuk melihat hubungan yang terjadi yaitu pengembangan hubungan Friends with Benefit melalui komunitas virtual yang terjadi di media sosial Whisper.

Proses pengumpulan data yang dilakukan peneliti dalam mengumpulkan data penelitian adalah melalui wawancara virtual dan observasi dilakukan dengan cara mengamati halaman media sosial Whisper dan mengamati timeline pada komunitas virtual FWB. Pengambilan sample yang digunakan yaitu purposive sampling. Wawancara dilakukan kepada informan yang tinggal di wilayah Kota Jakarta dengan status sosial ekonomi beragam, terdiri dari kelas atas sampai kelas menengah.

Kondisi psikologis pada informan penelitian ini yaitu sedang merasakan kesepian dan memiliki latar belakang pengalaman masa lalu terkait percintaan yang berbeda-beda. Adayang memiliki pengalaman trauma dengan hubungan komitmen dan ada yang tidak memiliki pengalaman apapun terkait hubungan percintaan di masa lalu.

Wawancara dilakukan oleh remaja laki-laki maupun perempuan yang berusia $18-22$ tahun dan berstatus sebagai mahasiswa sebanyak empat orang. Dalam penelitian ini peneliti menggunakan teknik analisis data Miles dan Huberman (1992) dalam tiga tahapan, yaitu: 1) Membangun sajian penelitian. Peneliti membuat sajian data penelitian yang diteliti, yaitu dimulai 
dari mengumpulkan referensi dari penelitianpenelitian terdahulu terkait dengan online dating dan fenomena Friends with Benefit sehingga peneliti membuat sajian data berdasarkan konsep dan dimensi berdasarkan temuan dari penelitian sebelumnya; 2) Memasukan data. Peneliti sedang mencari perubahan-perubahan dalam inovasi data tersebut, komponen demi komponen. Perubahan-perubahan itu dapat ditempatkan dalam catatan-catatan lapangan seperti hasil wawancara dengan seseorang yang menjalankan hubungan Friends with Benefit; 3) Menganalisis data. Peneliti dapat memahami lebih dalam mengenai hal yang terjadi kepada informan mengenai kejadian-kejadian hubungan online dating, dengan mengacu kembali pada aspekaspek lain dari catatan lapangan, khususnya yang dikatakan oleh informan yang ditulis melalui hasil wawancara melalui media sosial Whisper.

\section{Hasil Penelitian dan Pembahasan \\ Kedekatan atau Keakraban dalam Menjalin Hubungan Friends with Benefit di Media Sosial Whisper}

Pada tahap awal menjalankan hubungan Friends with Benefit di media sosial Whisper seseorang memiliki rasa percaya kepada pasangannya yaitu jika memiliki sikap dan tujuan yang sama dengan dirinya. Jika sikap seseorang yang dijadikan pasangan FWB tidak memiliki kesamaan maupun kecocokan maka kepercayaan sulit dibangun apalagi untuk dilanjutkan pada tahapan berikutnya. Sikap dan tujuan diketahui dari interaksi obrolan melalui pesan chatting yang dilakukan kepada pasangan FWB. Keseriusan seseorang dalam melakukan tahap awal hubungan FWB terlihat dari wawasan pengetahuannya terhadap obrolan yang disampaikan. Menurut informan I bahwa kepercayaan terhadap pasangan FWB dimulai dari komunikasi dan sifat dari pasangan. "Kan kita dari awal udah kenalan dan komunikasi juga sama orang yang udah kita liat-liat cocok, karena sifat dia sih makanya bisa percaya anaknya asik jadi ya fine fine saja. Makanya percaya." (Informan I, 02 Desember 2019).
Merujuk pada hasil wawancara oleh informan I dapat disimpulkan bahwa ketika melakukan interaksi obrolan melalui pesan chating kepercayaan dilihat dari umpan balik yang diberikan satu sama lain hal ini berkaitan dengan komunikasi yang dilakukan. Keseriusan seseorang dalam melakukan tahap awal hubungan FWB akan terlihat dari wawasan pengetahuannya terhadap obrolan yang disampaikan. Penelitian yang dilakukan oleh Sa'adatina dan Manalu (2017) yang berjudul penggunaan media sosial dalam dinamika hubungan pacaran, menunjukkan bahwa tingkat keintiman juga berdampak pada suatu hubungan, di mana keintiman tersebut dapat menyeimbangkan antara penggunaan media sosial dengan kepuasan hubungan. Kedekatan dalam hubungan FWB keintiman masing-masing pihak dapat terjadi tanpa adanya hubungan status pacaran, melainkan hanya merasakan rasa percaya karena sifat masing-masing pasangan yang terlihat melalui pesan chatting sehingga hubungan yang terjadi dapat terjalin secara seimbang. Seperti yang disampaikan oleh informan I bahwa kepercayaan terhadap pasangan FWB dimulai dari komunikasi dan sifat dari pasangan.

Pada tahap kedekatan seseorang juga harus memiliki konsep diri yang baik kepada pasangan. Konsep diri yang baik yang dilakukan oleh seseorang yang menjalankan hubungan Friends with Benefit di media sosial Whisper adalah orang yang mampu memposisikan dirinya di depan pasangan FWB. Awal kedekatan hubungan Friends with Benefit masing-masing pasangan biasanya merasakan kenyamanan satu dengan yang lain.

Hal ini dapat terjadi karena interaksi obrolan melalui media sosial Whisper terjalin cukup intens diantara keduanya. Hal menarik ketika menjalankan hubungan FWB yang dijalin melalui media sosial Whisper adalah rasa nyaman terbentuk ketika keduanya belum masuk pada tahap pertemuan. Artinya masing-masing pihak belum bertemu atau bertatap muka satu dengan yang lain. Saat menjalankan hubungan FWB di media sosial pada umumnya hubungan biasa memiliki sejumlah aturan, seperti harus memberi kabar satu dengan yang lain maupun aturan tidak boleh mendekati lawan jenis lain. 
Berbeda ketika menjalankan hubungan FWB, saat menjalankan hubungan FWB tidaklah membutuhkan sebuah aturan mengikat karena pada dasarnya FWB bukanlah hubungan yang terikat komitmen satu sama lain. Saat menjalankan hubungan FWB, masing-masing pihak sepakat tidak ada aturan dalam menjalankan hubungan FWB.

Tidak adanya aturan yang mengikat memiliki arti bahwa masing-masing pihak yang menjalankan hubungan FWB bebas melakukan apa saja seperti, memiliki pasangan lain, mendekati pasangan lain maupun tidak adanya aturan dalam intensitas pemberian kabar masing-masing pihak. Tidak ada aturan di antara keduanya ada juga yang tidak mendekati lawan jenis lain dimana dirinya memilih untuk tidak mendekati lawan jenis lain alasannya yaitu, tetap menghargai perasaan pasangan FWB meskipun tidak adanya aturan khusus dalam menjalankan hubungan FWB. Ketika menjalankan sebuah hubungan biasanya masing-masing pihak menggantungkan dirinya kepada pasangannya.

Menggantungkan diri bisa dilakukan dalam banyak hal seperti pasangan memiliki peran langsung dan terlibat langsung dalam kehidupan sehari-hari pasangannya. Pada hal lain menggantungkan diri merupakan mengandalkan pasangan ketika membutuhkan suatu bantuan ataupun dalam menghadapi sebuah persoalan. Interaksi kedekatan yang dijalankan dengan pasangan Friends with Benefit melalui media sosial Whisper bergantung dari bagaimana sifat yang diberikan pasangan FWB kepada kita dan interaksi kedekatan bergantung dari kehadiran pasangan satu dengan yang lain.

Interaksi kedekatan dalam tahap ini biasanya digunakan untuk mengenal pribadi pasangan satu samalainapakahdirinyacocokuntukmenjalankan hubungan FWB atau tidak. Sifat dan kehadiran pasangan juga memengaruhi akankah hubungan berlanjut pada tahap selanjutnya atau tidak. "Tergantung orangnya gimanasih. Selama dia asyik, ya, kita gak bakalan susah mau mulai hubungan. Nah kalo pasangannya susah baru kita juga sulit mau interaksi. Solusinya, ya, berusaha humble aja meskipun sama orang baru, biar pasangan FWB juga asyik." (Informan I, wawancara, 02 Desember 2019).
Merujuk dari hasil wawancara di atas dapat disimpulkan bahwa interaksi yang terjalin antara dirinya dengan pasangan tergantung dari sifat yang diberikan oleh pasangan. Sifat yang diberikan yaitu seperti memberikan perhatian khusus kepada dirinya dan mendengarkan yang dirinya sampaikan.

Menjalin interaksi dengan pasangan FWB terkadang Informan I memiliki kesulitan karena interaksi yang dilakukan dirinya kepada pasangan bergantung dari sifat yang diberikan pasangan. Dalam hal melakukan interaksi kedekatan kesulitan lain yang ditemukan oleh informan I yaitu sulit untuk berbagi pemikiran dan perasaan kepada pasangan FWB. Peneliti menemukan bahwa saat menjalankan hubungan Friends with Benefit meskipun hubungan yang terjalin pada saat tahap awal kedekatan hanya melalui media sosial Whisper namun tidak terjadi permasalahan mengenai hubungan diantaranya. Permasalahan yang terjadi justru permasalahan pribadi. Permasalahan pribadi yang dialami tidak disebutkan oleh masing-masing informan secara spesifik karena hal tersebut berkaitan dengan privasi masing-masing. Cara menghadapi masalah pribadi ketika sedang menjalankan hubungan Friends with Benefit yaitu dengan cara bercerita mengenai permasalahan yang terjadi kepada pasangan FWB. Hal tersebut justru dapat mengurangi beban permasalahan yang terjadi.

\section{Keterbukaan Diri dalam Menjalin Hubungan Friends with Benefit di Media Sosial Whisper}

Pengungkapan informasi ditujukan untuk mengetahui kegiatan satu dengan yang lain, hal tersebut dilakukan bertujuan untuk mengetahui informasi mengenai satu dengan yang lain. Pengungkapan informasi dalam proses keterbukaan diri hal tersebut berkaitan dengan konsep teori penetrasi sosial yaitu terkait pembukaan diri. Pada teori penetrasi sosial pembukaan diri merupakan inti dari perkembangan hubungan.

Penelitian yang dilakukan oleh Buntaran dan Helmi (2015) berjudul Peran Kepercayaan Interpersonal Remaja yang Kesepian dalam Memoderasi Pengungkapkan Diri pada Media 
Jejaring Sosial Online mengungkapkan bahwa seseorang mampu mempercayai satu sama lain karena masing-masing merasa ada di satu komunitas atau tipe yang sama. Proses pengungkapan diri lebih mudah dan merasa nyaman satu dengan yang lain. Hasil penelitian menunjukkan bahwa kepercayaan interpersonal yang besar pada pengguna media jejaring sosial online merupakan temuan penting terkait modal sosial yang ada.

Remaja yang merasakan keadaan kesepian menggunakanjejaringmediasosial sebagaimodal sosial ketika berinteraksi (sebagai ikatan sosial dan media yang menjembatani) untuk mengatasi permasalahan psikologis dalam hal ini kesepian yang dialami. Pembukaan diri dapat secara umum didefinisikan sebagai proses pembukaan informasi mengenai diri sendiri kepada orang lain yang memiliki tujuan. Berbeda dengan yang terjadi dalam hubungan FWB yaitu penyampaian informasi yang disampaikan kepada pasangan FWB kebanyakan tidak sering dilakukan dalam proses keterbukaan diri pada teori penetrasi sosial biasanya informasi yang ada di dalam pembukaan diri adalah informasi yang signifikan.

Hal tersebut tidak terlepas dari topik pembicaraan yang diperbincangkan. Proses ini memungkinkan seseorang untuk saling mengenal ke dalam sebuah hubungan. Saat melakukan kedekatan satu dengan yang lain topik merupakan salah satu hal yang penting karena menjadi faktor penentu hubungan apakah hubungan Friends with Benefit dapat berlanjut pada tahap selanjutnya atau tidak. Topik pembicaraan yang dilakukan saat menjalankan hubungan Friends with Benefit di media sosial Whisper berbeda dengan hubungan relasi percintaan seperti pacaran.

Jika pada hubungan relasi percintaan seperti pacaran biasanya topik yang dibicarakan adalah mengenai hubungan keduanya dan arah hubungan dibicarakan lebih jelas kedepannya, berbeda dengan hubungan FWB. Topik yang dibicarakan tidak ada mengenai arah hubungan ataupun komitmen, melainkan keuntungan apa saja yang akan didapat ketika menjalankan hubungan Friends With Benefit. Seperti yang dialami oleh informan I dan III bahwa topik pembicaraan yang menarik yang diperbincangkan yaitu mengenai seks.
"Ya, kalau pembicaraan yang dilakukan biasanya emg selalu berkaitan sama seks, meskipun seks itu biasanya gak langsung tapi minimal masing-masing pihak sudah tahu sih kalau seks, ya, bakalan jadi tujuan utama gitu karena kan sama-sama juga pengin." (Informan III, 06-12-19). Merujuk pada hasil wawancara kepada informan III disimpulkan bahwa, pembahasan mengenai seks dianggap penting karena diharapkan dapat memenuhi kebutuhan biologis antar pasangan dan dapat terbuka satu dengan yang lain. Pada situasi seperti biasanya umpan balik diberikan secara spontan. Respon yang diberikan memengaruhi seberapa jauh keterbukaan diri dilakukan di dalam hubungan kepada pasangan FWB. Dalam hal ini, peneliti menemukan bahwa dalam melakukan obrolan ataupun perbincangan topik yang disampaikan mengalir saja tanpa direncanakan dahulu sebelumnya. Hal ini berkaitan dengan konsep keterbukaan diri yang ada pada teori penetrasi sosial yaitu, dalam situasi hubungan FWB dimana dalam beberapa hubungan, cenderung untuk merencanakan yang dikatakan pada orang lain, namun dalam situasi lainnya, dalam konsep keterbukaan diri mungkin obrolan yang terjadi dilakukan secara spontan tanpa sebelumnya direncanakan terlebih dahulu (Altman dan Taylor, 1973).

Kondisi saat sedang menjalankan hubungan Friends with Benefit di media sosial Whisper dipilih pada saat sedang merasakan kesepian. Hubungan tersebut dipilih karena dianggap sebagai solusi untuk mengatasi rasa kesepian tersebut. Saat menjalankan hubungan FWB, biasanya seseorang dianggap kondisi sosial ekonomi yang rendah ataupun tidak mampu. Hal tersebut karena hubungan FWB merupakan sebuah hubungan yang menghasilkan benefit atau sebuah keuntungan, sehingga orangorang yang menjalankan hubungan ini merasa dianggap memiliki kondisi ekonomi yang rendah.

Padahal berdasarkan temuan penelitian ditemukan bahwa justru orang-orang yang menjalankan hubungan FWB ini terbilang memiliki kondisi ekonomi yang mampu meskipun ada beberapa yang memiliki kondisi 
ekonomi cukup atau biasa aja. Kondisi ekonomi bisa dikatakan mampu yaitu terlihat dari ketika masing-masing informan menjalankan hubungan FWB. Saat melakukan pertemuan dengan pasangan FWB, pertemuan dilakukan di sebuah pusat perbelanjaan di pusat Kota Jakarta dan selalu mengajak hang out dengan membelikan sejumlah barang-barang yang cukup mahal kepada pasangan atas dasar keinginan dirinya sendiri, seperti skincare maupun barang-barang yang pasangan FWB inginkan.

Menjalankan hubungan Friends with Benefit biasanya didalamnya terdapat keuntungan pribadi ketika menjalankan hubungan itu. Keuntungan biasanya diperoleh dari kesepakatan hubungan yang telah dijalankan bersama. Biasanya keuntungan yang didapatkan yaitu pasangan FWB mampu memenuhi yang pasangan inginkan seperti sebagai tempat bercerita dan memenuhi hubungan biologis mengirimkan gambar vulgar kepada dirinya. Keuntungan pribadi yang didapatkan dalam tahap keterbukaan diri adalah keuntungan yang didapat melalui hubungan dia media sosial Whisper. Keuntungan pribadi dianggap dapat mengurangi stress dan permasalahan yang terjadi.

\section{Penetrasi dalam Hubungan Friends with Benefit}

Arus pesan pada hubungan Friends with Benefit terjadi ketika masing-masing pihak memberikan respon ataupun umpan balik satu dengan yang lain. Arus pesan yang terjadi dapat seperti memberikan pertimbangan ataupun memberi sebuah saran. Saran yang diberikan oleh pasangan juga sedikit memenuhi yang kedua belah pihak inginkan. Pertimbangan yang disampaikan kepada pasangan dapat dipahami satu dengan yang lain. Arus dua arah yang dialami yaitu seperti selalu mendengarkan yang pasangan FWB-nya katakan, contohnya seperti diberitahu untuk tidak pulang terlalu larut. Pasangan FWB-nya merasa memiliki sifat yang tanggung jawab kepada dirinya dan pesan yang disampaikan kepada pasangan dapat dipahami dan selalu mengerti satu dengan yang lain.
Setelah melewati fase kedekatan atau keakraban, pada hubungan Friends with Benefit biasanya jika sudah merasa cocok satu sama lain biasanya akan melakukan pertemuan untuk menjalankan hubungan lebih lanjut dan mendapatkan keuntungan satu sama lain. Menjalankan hubungan FWB saat ingin melakukan pertemuan biasanya diantara keduanya membuat kesepakatan seperti janji untuk mengatur waktu pertemuan yang terjadi diantara keduanya. Tidak ada hal spesial yang dipersiapkanketika petamakalipertemuanterjadi.

Durasi dalam menjalankan hubungan Friends with Benefit berbeda pada setiap individu yang menjalankan. Durasi ketika menjalin hubungan juga dipengaruhi oleh sikap dari masing-masing pasangan. Dalam menjalankan hubungan FWB intensitas pertemuan yang terjadi berbeda pada setiap pasangan. Pertemuan dengan pasangan FWB biasanya sebanyak seminggu tiga kali atau terkadang dua minggu hanya tiga kali. Pertemuan yang dijalankan dengan pasangan FWB tergantung dari masing-masing pihak yang menentukan apakah ingin melakukan pertemuan atau tidak.

Pada tahap awal seseorang bersedia menjalankan hubungan Friends with Benefit, sudah hal biasa ketika tujuan dijalankannya hubungan ini merupakan untuk mendapatkan sebuah keuntungan. Keuntungan yang didapatkan biasanya terjadi dalam dua fase yaitu fase kedekatan hubungan ketika masih berinteraksi melalui platform media sosial Whisper dan fase ketika sudah terjadi pertemuan. Pada tahap penetrasi dibahas mengenai keuntungan ketika keduanya sudah mencapai pada tahap melakukan pertemuan.

Berdasarkan data temuan yang diperoleh bahwa keuntungan yang didapat yaitu dapat berhubungan seksual dengan pasangan FWB. Dalam kasus ini seseorang yang menjalankan hubungan FWB mengaku bahwa jika dalam hubungan pacaran tidak mendapatkan hal semacam itu dengan mudah, terlebih lagi harus menjalankan komitmen dengan durasi waktu yang cukup lama. Maka dari itu berhubungan seksual dengan pasangan Friends with Benefit merupakan sebuah keuntungan menurut dirinya. 
Ada juga keuntungan lain yang didapatkan ketika menjalankan hubungan Friends with Benefit adalah dengan menghabiskan waktu bersama dengan pasangan dan dapat berhubungan secara fisik sebatas bergandengan tangan dan berpelukan karena dinilai lebih mudah untuk berbagi cerita dan obrolan satu sama lain serta dapat menghabiskan waktu lebih banyak kepada pasangan. Dirinya juga tidak memungkiri bahwa tetap melakukan hubungan seksual meskipun tidak terikat komitmen. Hal tersebut dilakukan untuk memenuhi keinginan masingmasing pihak ketika sedang membutuhkan.

Terkadang pertemuan menjaga kestabilan hubungan, namun tidak dapat dipungkiri jika konflik dapat terjadi bahkan sampai merenggangkan hubungan FWB itu sendiri. Permasalahan yang terjadi ketika sudah terjadi pertemuan yaitu seperti tidak menepati janji, munculnya perasaan lebih, dan munculnya kehadiran orang ketiga. Konflik yang terjadi dengan pasangan yaitu karena sudah berjanji untuk melakukan pertemuan tetapi tidak ditepati oleh pasangan, sehingga pihak yang lain merasa tidak bisa mendapatkan keuntungan atau merasa bahwa keuntungan yang ingin didapatkan jadi terhambat.

\section{Depenetrasi dalam Hubungan Friends with Benefit}

Terdapat alasan sehingga hubungan Friends with Benefit mencapai pada tahap yang paling renggang atau bahkan hubungan sudah tidak dilanjutkan kembali. Salah satu alasannya yaitu masing-masing pihak sudah tidak mau lagi mendengarkan pasangannya satu sama lain. Dalam hal ini yang dimaksud yaitu biasanya salah satu pihak sudah tidak mau mendengarkan yang pasangannya katakana atau beri penjelasan.

Masing-masing pihak sudah tidak mau mendengarkan yang pasangannya katakan, biasanya hal tersebut berpengaruh terhadap intensitas chatting dan pertemuan yang terjadi diantara keduanya, apakah intensitas tetap sama ataupun sudah berkurang. Konflik yang terjadi diantara hubungan sudah semakin merenggang dan sampai pada tahap ketidakberlanjutannya hubungan.
Salah satu konflik yang terjadi yaitu seperti obrolan sudah tidak direspon kembali oleh pasangan, sifat asli pasangan yang semakin terlihat dan tidak sesuai dengan yang diinginkan. Faktor kebosanan terhadap hubungan juga menjadi salah satu hal yang menyebabkan terjadinya konflik dalam sebuah hubungan. Pada saat intensitas chatting dan pertemuan sudah berkurang selanjutnya yang terjadi adalah masing-masing pihak sepakat untuk tidak melanjutkan hubungan Friends with Benefit kembali. Lalu selanjutnya yang dilakukan adalah hubungan FWB berakhir sehingga komunikasi yang dijalankan dengan pasangan melalui media sosial whisper sudah tidak terjalin kembali.

Salah satu pihak sudah merasa "baper" maka dirinya memilih untuk tidak melanjutkan hubungan namun dirinya tetap melakukan komunikasi secara intens melalui media sosial Whisper meskipun sudah tidak menjalankan hubungan. Penelitian ini menemukan bahwa media sosial Whisper memiliki peranan dalam dinamika hubungan Friends with Benefit. Penetrasi yang dilakukan secara online dalam menjalankan hubungan juga tentunya berbeda dengankomunikasitatapmuka, mulai daritahapan kedekatan menuju ke depenetrasi. Pada setiap tahapan hubungan, lebih menyisihkan waktunya untuk berinteraksi melalui media sosial Whisper sebagai pengganti komunikasi tatap muka.

Keunikan dari hubungan Friends with Benefit yaitu dimulai dari kepercayaan. Kepercayaan yang dibangun ketika menjalankan hubungan FWB dengan orang lain di media sosial Whisper dimulai ketika melakukan interaksi obrolan melalui pesan chatting. Dalam konteks pertukaran sosial, masa-masa awal hubungan dengan seseorang biasanya melihat penampilan fisik atau tampilan luar dari orang tersebut, kesamaan latar belakang, dan banyaknya kesamaan atau kesamaan terhadap hal-hal yang disukai atau disenangi.

Hal ini juga dianggap sebagai suatu keuntungan yang mendorong seseorang menjalankan suatu hubungan. Berbeda ketika menjalankan hubungan FWB melalui media sosial Whisper, tanpa seseorang membuat profil 
diri dengan foto berwajah tampan maupun melihat penampilan fisik, maka seseorang dapat tetap melakukan hubungan ini karena pada tahap awal yang dilihat bukanlah persoalan fisik melainkan dari bagaimana cara berinteraksi dengan lawan jenis melalui media sosial Whisper.

Perbedaan jenis kelamin antara perempuan dan laki-laki juga memiliki beberapa berbedaan antara realitas yang dijalankan saat menjalankan relasi hubungan di media sosial dan juga secara langsung. Saat menjalankan hubungan percintaan yang termediasi melalui media sosial Whisper, pihak perempuanlah justru lebih berperan aktif dalam membangun hubungan. Perempuan biasanya terus melakukan banyak aktivitas interaksi seperti pencarian topik dan melakukan intensitas obrolan yang lebih banyak sehingga hal tersebut membuat lawan jenis merasa nyaman satu sama lain.

Saat menjalankan hubungan FWB, biasanya seseorang menganggap bahwa faktor sosial ekonomi memengaruhi seseorang untuk menjalankan hubungan percintaan yang termediasi. Hal tersebut tidaklah menjadi tujuan utama seseorang menjalankan hubungan FWB, meskipun ada beberapa pihak yang menjelaskan bahwa dirinya melakukan hal tersebut karena kondisi keuangannya dan keadaan ekonominya. Tujuan utama seseorang menjalankan hubungan FWB yaitu tetap berorientasi pada hal-hal kesenangan semata dan karena permasalahan hubungan di masa lalu.

Hal lain yang menjadi perbedaan ketika menjalankan hubungan percintaan FWB yaitu, dari segi topik pembicaraan yang dibicarakan. Terdapat perbedaan ketika perempuan melakukan topik pembicaraan dengan pihak lakilaki. Jika perempuan lebih membahas seputar kehidupan sehari-hari dan aktivitasnya, maka justru pihak laki-laki memilih topik pembicaraan mengenai sex semata. Meskipun tidak semua laki-laki memilih topik hanya mengenai sex, namun berdasarkan temuan dapat dilihat bahwa laki-laki mengambil keuntungan dalam hubungan FWB ini yaitu dalam bentuk sex.
Hal-hal yang menarik pada hubungan ini yaitu ada pada keuntungan ketika menjalankan hubungan. Keuntungan pribadi lain yang didapatkan dari pasangan yaitu, pasangan FWB mampu memenuhi yang pasangan FWB nya butuhkan. Keuntungan yang didapatkan dari menjalankan hubungan FWB tidak hanya mengenai aktivitas seksual. Seperti penelitian yang dipaparkan oleh Putri (2015) bahwa FWB merupakan sebuah pergaulan bebas dimana orientasi utamanya yaitu hanya untuk mendapatkan seks semata. Temuan kali ini menunjukkan bahwa meskipun hubungan FWB tujuan utamanya adalah untuk mendapatkan keuntungan berupa seks namun terdapat hal lain yang didapatkan dan bukan hanya mengenai persoalan seks semata. FWB terkadang tidak hanya mengenai hubungan sex semata, keuntungan yang didapatkan dari hubungan fisik yang dilakukan setelah adanya pertemuan adalah seperti pelukan, ciuman bahkan sampai melakukan hubungan seksual.

Hubungan mulai tidak stabil atau biasanya salah satu pihak sudah merasa dirugikan, pada hubungan FWB pemutusan hubungan terjadi begitu saja. Jika pada hubungan percintaan pada umumnya seseorang mempertahankan hubungan yang telah dijalankan bersama pasangan dan mencari jalan keluar bersama ketika menghadapi permasalahan, berbeda dengan hubungan FWB yang tidak peduli dengan hubungan yang dijalankan ketika salah satu pihak sudah merasa dirugikan.

Saat masing-masing pihak merasa hubungan tidak sesuai pada kesepakatan awal, maka hubungan dapat berakhir begitu saja tanpa pertimbangan ataupun masing-masing pihak memertahankan. Hal tersebut berkaitan dengan konsep hubungan ini dimana hubunga ini adalah hubungan tanpa komitmen dan hanya berorientasi pada kesenangan semata. Meskipun satu sama lain telah mendapatkan keuntungan seperti berhubungan seksual, namun jika terjadi satu kesalahan saja maka hubungan FWB yang dijalin dapat terjadi pemutusan begitu saja. Permasalahan atau konflik yang terjadi ketika sudah melakukan pertemuan 
adalah seringnya tidak menepati janji ketika sudah merencanakan pertemuan sehingga hal tersebut membuat kekecewaan salah satu pihak.

Setelah melalui berbagai konflik sampai pada masing-masing pihak sudah tidak mau mendengarkan satu sama lain. Alasan sudah tidak mau lagi mendengarkan yang pasangan FWB katakan yaitu disebabkan oleh kehadiran pasangan FWB yang hilang-hilangan dan terlalu banyak alasan. Hal tersebut menyebabkan seseorang yang menjalankan FWB tidak mau mendengarkan yang pasangannya katakan. Disisi lain terdapat juga pihak yang berusaha menjelaskan permasalahan kepada pasangannya namun tida diberikan respon oleh pasangan FWB mengenai kejelasan hubungan.

Intensitas chatting juga sudah berkurang karena banyaknya persoalan seperti pasangan yang sudah hilang-hilangan dan sibuk dengan urusan pribadi, dan adanya batasan dalam pertemuan bahkan ada yang sudah tidak bertemu lagi karena hubungan semakin renggang. Pada tahap depenetrasi hubungan semakin renggang bahkan memilih untuk tidak melanjutkan. Hal tersebut karena masing-masing pihak sudah merasa hambar dan jenuh ketika menjalankan hubungan FWB. Bahkan ada pihak yang sudah memiliki hubungan diluar hubungan FWB. Hubungan sudah tidak terjalin lagi namun hubungan pertemanan tetap terjalin meskipun ada pihak yang sudah tidak menjalin hubungan FWB maupun pertemanan dengan pasangan FWB.

\section{Simpulan}

Peneliti ini menyimpulkan hal yang berkaitan dengan online dating dalam relasi percintaan Friends with Benefit di media sosial Whisper, yaitu: 1) Pertimbangan seseorang ketika menjalin kedekatan atau keakraban dalam relasi percintaan Friends with Benefit di media sosial Whisper, saat melakukan hubungan kedekatan atau keakraban masing-masing pihak menganggap hubungan FWB sebagai hiburan, memperluas relasi serta mencari teman. Sehingga mereka memiliki pemahaman mengenai kencan online melalui media sosial Whisper sebagai suatu hal yang positif dan efisien; 2) Pada tahap keterbukaan diri dalam menjalin relasi percintaan Friends with Benefit di media sosial Whisper, keterbukaan diri dianggap sebagai ajang curhat kepada FWB dan mengungkapkan beberapa hal terkait informasi pribadi yang bersifat privasi; 3) Pada tahap penetrasi dalam menjalin relasi percintaan Friends with Benefit di media sosial Whisper, dapat disimpulkan bahwa pasangan FWB akan melakukan pertemuan satu sama lain dimana masing-masing pihak biasanya akan meminta sebuah keuntungan sesuai dengan perjanjian di awal hubungan dimana kedua belah pihak sudah sepakati di awal hubungan; 4) Pada tahap depenetrasi dalam menjalin relasi percintaan Friends with Benefit di media sosial Whisper, konflikkonflik ketika menjalankan hubungan semakin terlihat yang disebabkan oleh ego dari masingmasing pihak karena hubungan FWB yang hanya didasarkan dari segi keuntungan semata.

Penelitian ini memberikan kontribusi berupa rekomendasi kebijakan pada pengguna aplikasi online dating terutama yang menjalankan hubungan FWB, agar lebih selektif dalam melakukan komunikasi hyperpersonal sehingga tidak melakukan tindakan berlebihan danmerusak citra atau nama baik. Peneliti juga berharap pengguna online dating mengetahui bahwa didalam pengembangan hubungan romantis, terdapat tahapan- tahapan yang dilalui yang melibatkankepercayaan, ketelitiandankeamanan.

\section{Daftar Pustaka}

Abadi, T. W., Sukmawan, F., \& Utari, D. A. (2016). Media sosial dan pengembangan hubungan interpersonal remaja di Sidoarjo. KANAL: Jurnal Ilmu Komunikasi, 2(1), 95106.https://doi.org/10.21070/kanal.v2i1.278

Altman, I., \& Taylor, D.A. (1973). Social penetration: The Develompent or Interpersonal Relationship. New York: Holt, Rinehart, \& Winston. Andhika R. \& Julianti. (2021). Fenomena Keberhasilan Hubungan Asmara melalui Aplikasi Kencan Online Tinder: Dari Jari, Turun ke Hati. Jurnal Ilmu Komunikasi UHO. 6(1), 1-18. 
Andriani I., Diana I., Siti K. U. (2019). Pengaruh Harga Diri dan Kepercayaan terhadap Diri pada Pengguna Aplikasi Kencan Online. Motiva. 2(2), 66-73 Arvidsson, A. (2006). Brands Meaning and Value in Media Culture. London \& New York: Routledege. Ayun, P.Q. (2015). Fenomena Remaja Menggunakan Media Sosial Dalam Membentuk Identitas. Jurnal Channel, 3(2), 1-16. http://dx.doi. org/10.12928/channel.v3i2.3270.

Bahfiarti, T. (2014). Pengembangan Hubungan dalam Komunikasi Antarpribadi Mantan Narapidana Perempuan Bugis-Makassar. Jurnal Ilmu Komunikasi, 10(3), 272-284.

Ben-Ze-ev. \& Aaron. (2004). Love Online: Emotions on the Internet. New York: Cambridge University Press.

Cessia, K. D., \& Lestari, S. B. (2017). Pemahaman Pengguna Media Sosial Tinder terhadap Fenomena Kencan Online untuk Menjalin Hubungan Romantis Bagi Penggunanya. Interaksi Online, 6(1), 1-10.

Fiore, A. (2008). Self-presentation and deception in online dating. California: School of Information University of California.

Buntaran, F. A. A., \& Helmi, A. F. (2015). Peran Kepercayaan Interpersonal Remaja Yang Kesepian Dalam Memoderasi Pengungkapan Diri Pada Media Sosial Online. Gadjah Mada Journal of Psychology (GamaJoP), 1(2). Diakses dari https://journal. ugm.ac.id/gamajop/article/view/7348.

Hikmah, N., \& Rahardjo, T. (2018). Keterbukaan Komunikasi dalam Relasi Romantik. Interaksi Online, 6(4), 268-285. Indriyati, R. (2015). Fenomena Dating Relationship Di Media Sosial. Prosiding SNaPP: Sosial, Ekonomi dan
Humaniora, 5(1), 731-734. Diakses dari http://proceeding.unisba.ac.id/ index.php/sosial/article/view/424. Lawado M.R. \& Puspita S. S. (2020). Komunikasi Antarpersonal pada Pasangan Berbasis Aplikasi Kencan Online (Studi Deskriptif Mahasiswa Neger Surabaya Pengguna AplikasiTinder).Commercium.2(2), 113-118.

Mellania, C., \& Tjahjawulan, I. (2020). Pencarian Jodoh Daring Masyarakat Urban Indonesia: Studi Kasus Aplikasi Tinder dan OkCupid. JSRW (Jurnal Senirupa Warna), 8(1), 19-37. Miles, B.M \& Huberman, M. (1992). Analisis Data Kualitatif Buku Sumber Tentang Metode-metode Baru. Jakarta: UIP.

Putri, M.G. (2015). Friends with Benefits (FWB) (Studi Tentang Pergaulan Bebas Mahasiswi UIN Sunan Kalijaga Yogyakarta). Fakultas Ilmu Komunikasi UIN Sunan Kalijaga.

Sa'adatina, \& Manalu, S. R. (2017). Penggunaan Media Sosial Dalam Dinamika Hubungan Pacaran: Studi Terhadap Penggunaan Instagram Pada Pasangan Berpacaran. Interaksi Online, 5(4), 1-10. Diakses dari https://ejournal3.undip.ac.id/index. php/interaksi-online/article/view/17472 Sari, W. P., \& Kusuma, R. S. (2018). Presentasi Diri dalam Kencan Online pada Situs dan Aplikasi Setipe dan Tinder. Mediator: Jurnal Komunikasi, 11(2), 155-164. https:// doi.org/10.29313/mediator.v11i2.3829 Sari W. P. \& Rina S. K. (2018). Presentasi Diri dalam Kencan Online pada Situs dan Aplikasi Setipe dan Tinder. MediaTor. 11(2), 155-164 Žakelj, T., Kocon, D., Švab, A., \& Kuhar, R. (2015). Internet Dating As A Project: The Commodification And Rationalisation Of Online Dating. Druzboslovne Razprave, 31(78). 